\title{
Bio-scouring of Non-spinnable Cotton by a Crude Enzyme of a New Fungal Strain Aspergillus sp. VM-1, Isolated from Banana Pseudostem Waste
}

\author{
P. Jagajanantha ${ }^{1} \cdot$ Mukul Morey $^{1} \cdot$ Varsha Satankar $^{1} \cdot$ V. Mageshwaran ${ }^{2} \mathbb{D}$
}

Received: 1 April 2021 / Accepted: 18 October 2021 / Published online: 3 November 2021

(c) The Author(s), under exclusive licence to Springer Nature B.V. 2021

\begin{abstract}
In the present study, we isolated and identified a new fungus, Aspergillus sp VM-1 from banana pseudostem waste. The fungal strain, Aspergillus sp. VM-1 was grown on a substrate (banana pseudostem, cottonseed hulls and cottonseed meal in the ratio of 60:30:10, respectively) for 7 days and the crude enzyme was extracted from the fermented substrate. The pectinase activity in crude enzyme extract was 551 (U/ml). The crude enzyme extracted from Aspergillus sp. VM-1 was evaluated for bio-scouring of non-spinnable cotton. The non-spinnable cotton taken in the study was short staple cotton (SSC), cotton linters (CL) and non-woven cotton fabric (NWCF). The maximum absorbency ( $2 \mathrm{~s}$ ) in non-spinnable cotton was achieved under optimized process conditions: enzyme extract level $(40 \%)$, temperature $\left(40 \pm 2{ }^{\circ} \mathrm{C}\right)$ and time $(40 \mathrm{~min})$. The quality parameters of bio-scoured cotton meet the Indian Pharmacopoeia (IP) standards. A solid state fermenter was designed to scale-up the crude enzyme production up to 301 . This is the first report on bio-scouring of under-utilized short cotton fibres at lower temperature $\left(40 \pm 2{ }^{\circ} \mathrm{C}\right)$. The present study offers a simple and eco-friendly bio-scouring process as an alternative to toxic chemical scouring of under-utilized short staple cotton fibres.
\end{abstract}

V. Mageshwaran

mageshwaran.v@icar.gov.in; mageshbioiari@gmail.com

1 ICAR-Central Institute for Research on Cotton Technology, Mumbai, Maharashtra 400019, India

2 ICAR-National Bureau of Agriculturally Important Microorganisms, Mau, Uttar Pradesh 275103, India 


\section{Graphic Abstract}

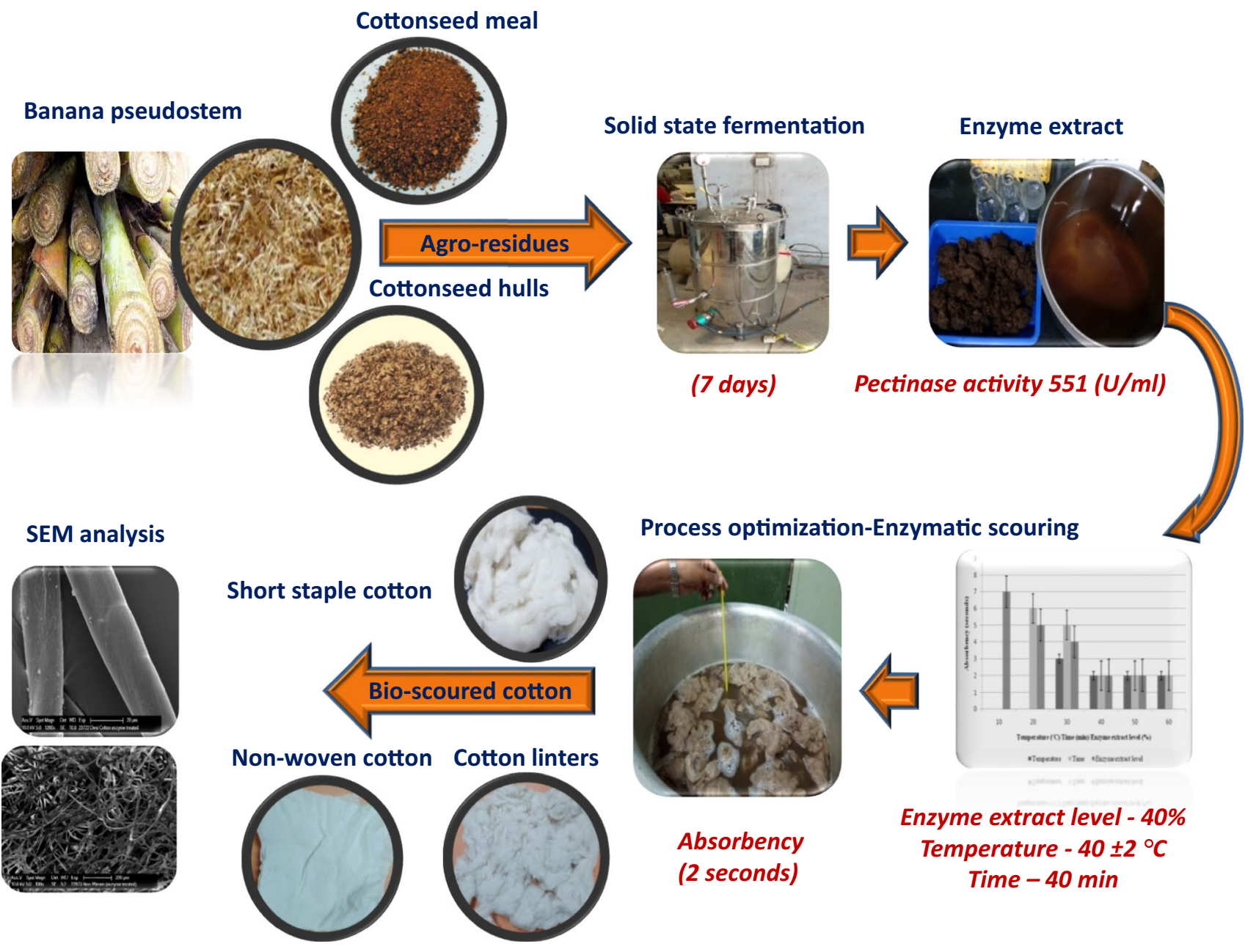

Keywords Aspergillus sp. B Banana pseudostem $\cdot$ Bio-scouring $\cdot$ Crude enzyme $\cdot$ Non-spinnable cotton

\section{Statement of Novelty}

The chemical scouring of cotton causes irreparable damage to the environment. This work reports an eco-friendly and low temperature bio-scouring of underutilized non-spinnable cotton using a crude enzyme produced by a new fungal strain, Aspergillus sp. VM-1.

\section{Introduction}

The area and production of cotton for the year 2019-2020 in the world are $33 \mathrm{Mha}$ and $26 \mathrm{Mt}$, respectively [1]. The major cotton producing countries are India, China USA, Brazil, Egypt, Australia and Pakistan. Cotton is highly preferred fibre in textile industry due to its softness, comfort and high water retention capacity. About 6 to $10 \%$ of cotton generated during cultivation as well as processing is made up of short fibres which could not be woven and it is called non-spinnable cotton. The linters are short fuzzy fibres $(<10 \mathrm{~mm}$ staple length) obtained from ginned cottonseed after delinting process. The short staple cotton (G. arboreum) is having the staple length of $<26 \mathrm{~mm}$ and being cultivated in selected areas of India. These short fibres contain $80 \%$ cellulose and finds potential application in absorbent cotton preparation. The demand for absorbent cotton is growing at the rate of 10 percent annum and the estimated demand of absorbent cotton in India is 2 million bales (of $170 \mathrm{~kg}$ each) per year [2]. Considering the recent outbreak of COVID-19, nonwoven cotton has become the ever-growing sector in the global textile industry due to increasing consumer's preference towards sustainable and biodegradable disposable products. Non-woven cotton has the superior characteristics of absorbency, comfort, disposability and sanitation value [3]. 
Non-woven and absorbent cotton are ideal for applications such as in absorbing body fluids during surgery, wound healing treatment, ear buds, cosmetic wipes, baby diapers, adult incontinence products, hygiene products, cleaning wipes, medical bandages, equine bandages etc. Conventionally, the absorbent cotton is prepared by chemical scouring of cotton at higher temperature $\left(100-110^{\circ} \mathrm{C}\right)$ and pressure (15 psi) under alkaline conditions ( $\mathrm{pH} 12)$. Absorbent cotton industry is looking for eco-friendly and economically competitive process as an alternative to conventional process which consumes high energy, water and chemical [4]. Commercial pectinase was used in the preparation of absorbent cotton $[5,6]$; however, it is not cost effective. Agro-residues are used as the cheap substrate for the production of pectinase at industrial scale [7-9]. In our earlier attempt, we showed the bio-scouring potential of crude enzyme produced by Pleurotus flabellatus in preparation of absorbent cotton from short staple cotton [10]. However, the pectinase activity of P. flabellatus recorded was low $(28.1 \mathrm{U} / \mathrm{ml})$. The present study was aimed to identify a new fungal strain capable of producing high titre of pectinase which is suitable for bio-scouring of different short fibres materials and to scale-up the enzyme production using a newly designed solid state fermenter.

\section{Materials and Methods}

\section{Non-spinnable Cotton}

Short staple cotton fibres (Phule Dhanwantry var.) were procured from ICAR- Central Institute for Cotton Research, Nagpur, India. The cotton linters were obtained from M/s Gimatex, Hinganghat, India. The staple length of short staple cotton and cotton linters were 20.8 and $8 \mathrm{~mm}$ respectively. The obtained short fibres were detangled using trash separator. Non-woven cotton fabric was obtained from M/s Welspun India Pvt. Ltd., Mumbai, India. It was composed of 95\% short staple cotton and 5\% viscose rayon with $40 \mathrm{~g}$ per square meter (GSM).

\section{Microorganisms}

The fungus culture, Pleurotus flabellatus was obtained from Microbiology Laboratory of Ginning Training Center, ICAR-CIRCOT, Nagpur. The fungal strains, $P$. flabellatus and Aspergillus sp. VM-1 were grown in malt extract broth $(1 \times)$ (Himedia, India) for $48 \mathrm{~h}$ and maintained in malt extract agar slant at $4{ }^{\circ} \mathrm{C}$.

\section{Substrates for Solid State Fermentation}

The agro residues such as banana pseudostem wastes, cottonseed hulls and cottonseed meal, were purchased from local market. These substrates were dried in a hot air oven, powdered using pulverizer and passed through $1 \mathrm{~mm}$ sieve. The substrates thus prepared were used for solid state fermentation.

\section{Isolation and Identification of Aspergillus sp. VM-1}

While working with P. flabellatus for extraction of crude enzyme in absorbent cotton treatment as described in our previous work [10], the fungal strain Aspergillus sp. VM-1 was occurred as an extraneous in solid state fermentation medium containing banana pseudostem. The better bioscouring property of crude enzyme from this extraneous fungus instigated us to isolate this organism. It was isolated by serial dilution plate technique using Martin Rose Bengal agar medium (Himedia, Mumbai, India). The microscopic characterization of the fungal isolate was done by phase contrast microscope. The molecular identification of fungal isolate was done by sequencing of Internal Transcribed Spacer (ITS) region. The fungal DNA was isolated with the help of Nucleopore kit gDNA fungal bacterial minikit (Genetix Biotech Asia (P) Ltd., New Delhi, India). The isolated DNA was amplified by polymerase chain reaction (PCR) using the primer set of ITS (ITS1F (TCCGTAGGTGAACCTGCG G) and ITS4R (TCCTCCGCTTATTGATATGC)) [11]. The PCR conditions were as follows: a. initial denaturation at $95{ }^{\circ} \mathrm{C}$ for $5 \mathrm{~min}$ b. 30 cycles of denaturation at $95{ }^{\circ} \mathrm{C}$ for $1 \mathrm{~min}$, annealing at $55^{\circ} \mathrm{C}$ for $45 \mathrm{~s}$ and an extension at $72{ }^{\circ} \mathrm{C}$ for $1 \mathrm{~min}$. c. final extension at $72{ }^{\circ} \mathrm{C}$ for $10 \mathrm{~min}$. The amplicons of 18S rDNA was resolved in 1.2\% agarose gel using $1 \mathrm{X}$ TAE buffer at $70 \mathrm{~V}$ and the PCR amplicons were purified and sequenced. The nucleotide sequence of fungal isolate was compared by BLAST with existing database at NCBI website (http://www.ncbi.nlm.nih.gov/BLAST) to identify its closest neighbor. The GenBank accession no. of Aspergillus sp. VM-1 was obtained and the fungal culture was deposited under general deposit at National Agriculturally Important Microorganisms Culture Collection (NAIMCC), Mau, Uttar Pradesh, India.

\section{Solid State Fermentation}

Solid state fermentation was carried out in one liter conical flask containing $100 \mathrm{~g}$ of substrate (banana pseudostem, cottonseed hulls and cottonseed meal in the ratio of 60:30:10). Eighty milliliter of distilled water was added to maintain initial moisture content [up to $80 \%(\mathrm{v} / \mathrm{w})$ ]. The moistened substrate was autoclaved at $121{ }^{\circ} \mathrm{C}$ for $15 \mathrm{lbs} / \mathrm{in}^{2}$ for $20 \mathrm{~min}$. After cooling, the substrate was inoculated with $5 \mathrm{ml}$ of 
48 h old fungal strain, Aspergillus sp. VM-1 (5\% inoculum grown in malt extract broth) and incubated for one week at $30 \pm 2{ }^{\circ} \mathrm{C}$.

\section{Enzyme Extraction}

The enzyme was extracted by adding total one liter of distilled water in the one week old fermented substrate, stirred for $30 \mathrm{~min}$ and filtered through muslin cloth. The enzyme extract was stored at $4{ }^{\circ} \mathrm{C}$ until use.

\section{Pectinase Activity}

The pectinase activity in crude enzyme was determined by estimation of polygalactouronase activity and analysis of reducing sugars released from citrus pectin during the reaction [12]. One unit of enzymatic activity (U) was defined as the amount of enzyme which releases one $\mu \mathrm{mol}$ of galactouronic acid per minute.

\section{Optimization of Bio-scouring Process Parameters}

The process parameters, such as enzyme extract level; temperature and time were optimized for bio-scouring of nonspinnable cotton. Single factor experiments were conducted for process optimization. Five gram of non-spinnable cotton (SSC, CL and NWCF) was taken in $100 \mathrm{~mL}$ of liquor solution in each treatment. The liquor solution consists of varied level of enzyme and finally made up to $100 \mathrm{ml}$ with distilled water. Thus, the material to liquor ratio (MLR) was maintained as 1: 20 in all treatments. Care was taken that fibre was immersed completely in the bath. The bio-scouring experiment was carried out in reciprocating water bath (Rivotek TC 344, Rivera, India). The constant parameters were MLR (1:20), pH 6 to 6.5 and non-ionic wetting agent (Empi 100®) addition @ 0.05\%)while the variable parameters were enzyme extract level $(10,20,30,40$ and 50\%), temperature $\left(30,40,50\right.$ and $\left.60^{\circ} \mathrm{C}\right)$ and time $(20,30,40,50$ and $60 \mathrm{~min})$. The enzyme extract level (10, 20, 30, 40 and $50 \%)$ and their corresponding pectinase activity (U/ml) in the bath were 55, 110, 165, 220 and 275.

After treatment, the sample was cooled and washed 4-5 times in running tap water, squeezed and removed water, dried in oven at $100{ }^{\circ} \mathrm{C}$ for $4 \mathrm{~h}$. The dried cotton was tested for absorbency (s) according to IS 2369-1967 after certain modification [13]. Each treatment was replicated and the average value of each set of experiments was taken into account. As per Indian Standard, the sinking time in seconds (s) is considered to calculate the absorbency. The shorter the time taken for a specimen to sink, the greater is its absorbency. For NWCF, $1 \mathrm{~g}$ of sample was cut, folded to a size of $5 \mathrm{~cm}^{2}$ and kept under a load of $1 \mathrm{~kg}$ for $10 \mathrm{~min}$ and tested immediately. For SSC and CL, $1 \mathrm{~g}$ of sample was taken and compressed in a glass tube of $32 \mathrm{~mm}$ bore diameter to form pellets of length about $25 \mathrm{~mm}$. The sample prepared in this way was gently dropped with a pair of forceps into a container of about $3 \mathrm{~L}$ capacity, containing distilled water maintained at $27 \pm 2{ }^{\circ} \mathrm{C}$ temperature, having water column about $15 \mathrm{~cm}$. The time interval between the specimen touching the surface of water and its complete sinking under the surface was noted using a stop watch.

\section{Scale-Up of Crude Enzyme Production by Solid State Fermenter}

A solid state fermenter was designed to scale-up the crude enzyme production for bioscouring treatment of non-spinnable cotton. The design of the fermenter was made using CAD software (SOLIDWORKS $®$, USA). The designed fermenter has the capacity to produce $30 \mathrm{~L}$ of enzyme. The body construction of fermenter was made using stainless steel. The ferementer consists of three trays, one porous plate to be kept at bottom, the upper lid, one heating rod at bottom. The physical dimensions of the fermenter are given in supplementary file 1 . The fermenter was designed specifically to carry out autoclaving and fermentation in a single vessel. The heating element was kept immersed in the water at bottom to generate steam in the vessel. The porous plate placed in the bottom allows the steam to pass through the entire vessel. The upper lid was fitted with the pressure gauge, temperature control and safety valve. The upper lid was tightly closed using 10 cap screws along with rubber seal. The substrate (banana pseudostem: cottonseed hulls and cottonseed meal powder in the ratio 60:30:10, respectively) was kept in the steel trays and autoclaved at $121{ }^{\circ} \mathrm{C}, 15 \mathrm{lbs} / \mathrm{in}^{2}$ for $15 \mathrm{~min}$. One $\mathrm{kg}$ of substrate was kept in each vessel. The autoclaved substrate was kept for cooling overnight. Next day, the substrate was inoculated with P. flabellatus/Aspergillus sp.VM-1 @ 5\% inoculum and incubated at room temperature $\left(30 \pm 2{ }^{\circ} \mathrm{C}\right)$ for one week. Aeration was provided with the help of compressor with the inlet pressure of $(0.2$ bar) throughout the fermentation period. The enzyme extraction and pectinase estimation in crude enzyme extract was done as described earlier.

\section{Characterization of Bio-scoured Non-spinnable Cotton Material}

The bio-scoured non-spinnable cotton (SSC, CL and NWCF) processed under optimized conditions was characterized for $\mathrm{pH}$, water holding capacity $(\mathrm{g} / \mathrm{g})$, sulphated ash content (\%), wax content (\%) other than absorbency (s) as described by $[2,6]$. The set of experiments were repeated twice and the average value was taken into consideration. 


\section{SEM Analysis of Bio-scoured Non-spinnable Cotton Material}

The surface modification in the treated samples (SSC, CL and NWCF) was observed using SEM (Philips XL-30) with an accelerating voltage of $12 \mathrm{kV}$. The sample was coated with a thin layer of conducting material (gold/palladium) using a sputter coater.

\section{Economic Analysis of Enzymatic Bio-scouring}

The cost analysis including substrate, culture and process were done to estimate the running cost involved in production of $1 \mathrm{~kg}$ of bio-scoured cotton.

\section{Results and Discussion}

Cotton is a foremost fibre crop grown world-wide and it is the most preferred fibre in textile sector especially for fabrics and apparels. Cotton processing generates enormous amount of short fibres that have no value for textile applications because of their short staple length. They are collectively called as non-spinnable cotton. However, the richness of cellulosic content in short fibres attracts researchers to utilize them for preparation of absorbent cotton and other value-added products such as cellulose powder, bio-ethanol, animal feed, etc. The raw cotton contains $86-96 \%$ cellulose and $6-14 \%$ of non-cellulosic impurities. The pectin and the waxes are the major impurities present in cotton. Pectin binds with waxes on the outer layer of fibre and is responsible for non-absorbent characteristic of cotton. Pectinase acts on pectin layer in fibre and releases waxes from the surface of cotton. This action improves the absorbent characteristics of cotton. The use of commercial pectinases for absorbent cotton preparation is well reported [14-16]. Scouring is the process of removing non-cellulosic material from the cotton fibres while bio-scouring uses enzymes in place of $\mathrm{NaOH}$ and it is a vital process for cellulosic fibre to provide absorbency. The conventional scouring process generates toxic effluents in the environment due to large use of alkali in the process. Enzymatic scouring is an alternative to conventional alkali method which helps in significant reduction in release of toxic chemicals in to the environment $[5,6]$.

\section{Solid State Fermentation and Pectinase Activity}

The present study attempts to develop a cost-effective bioscouring process for the under-utilized short staple cotton fibres (SSC, CL and NWCF). Crude enzyme extract obtained from solid state fermentation of agricultural residues was used for bio-scouring process. In our previous work, we showed the bio-scouring potential of $P$. flabellatus in preparation of absorbent cotton from SSC. Pectinase enzyme plays important role in bio-scouring of cotton [5]. Pectinase activity of crude enzyme obtained from P. flabellatus was $28.1 \mathrm{U} / \mathrm{ml}$ [10]. P. flabellatus was grown in solid state fermentation media containing banana pseudostem, cottonseed hulls and cottonseed meal in the ratio 60:30:10, respectively. The bioscouring enzyme, pectinase is industrially produced by solid state fermentation. Agro-residues are the cheapest and largely available source for solid state fermentation [17, 18].

In this study, a new fungal strain, Aspergillus sp. VM-1 was isolated from a solid state fermentation medium containing banana pseudostem. The ITS sequence of fungus was submitted to NCBI database and GenBank accession no. MT 568613.1 was obtained. The fungus culture was deposited to IDA authorized culture collection NAIMCC and accession no. F-03976 was obtained (supplementary file 2). The pure culture of Aspergillus sp. VM-1 was inoculated in solid state fermentation medium containing banana pseudostem, cottonseed hulls and cottonseed meal in the ratio 60:30:10, respectively. The pectinase acivity of Aspergillus sp. VM-1 was found to be $551(\mathrm{U} / \mathrm{ml})$ which was much higher than $28.1(\mathrm{U} / \mathrm{ml})$ as reported earlier in $P$. flabellatus. In a similar work, a low cost agro-waste (banana peel) was used for production of high activity pectinase by a fungus, Aspergillus niger [19].

\section{Optimization of Bio-scouring}

The effect of process parameters such as time (min), temperature $\left({ }^{\circ} \mathrm{C}\right)$ and crude enzyme level (\%) was optimized for bio-scouring of non-spinnable cotton while the parameters, MLR (1:20), pH 6 to 6.5 and non-ionic wetting agent (Empi 100®) addition @ 0.05\% were kept constant. The results showed that the optimized parameters are time (40 $\mathrm{min})$, temperature $\left(40{ }^{\circ} \mathrm{C}\right)$ and crude enzyme extract level (40\%). The absorbency (seconds) recorded under optimized conditions was 2 (Fig. 1). The absorbency is inversely related to sinking time (seconds), which means lower sinking time implies higher absorbency. The increase in crude enzyme extract level resulted in increase in absorbency up to certain extent (40\%). Thus, there is a correlation exists between pectinase activity and absorbency and it was found that the correlation co-efficient $\left(r^{2}=0.938\right)$ (Fig. 2). Presently, bio-scouring involves the use of commercial pectinase with optimum temperature of $50-65^{\circ} \mathrm{C}$ and $\mathrm{pH} 7.5-9.0$ [5, 6, and 20]. The results of the present study indicated a new process of bio-scouring and not reported earlier in which the optimum temperature and $\mathrm{pH}$ was $40^{\circ} \mathrm{C}$ and $6-6.5$, respectively. 
Fig. 1 Effect of process parameters on bio-scouring of non-spinnable cotton
Fig. 2 Relationship between pectinase activity of crude extract and absorbency of nonspinnable cotton
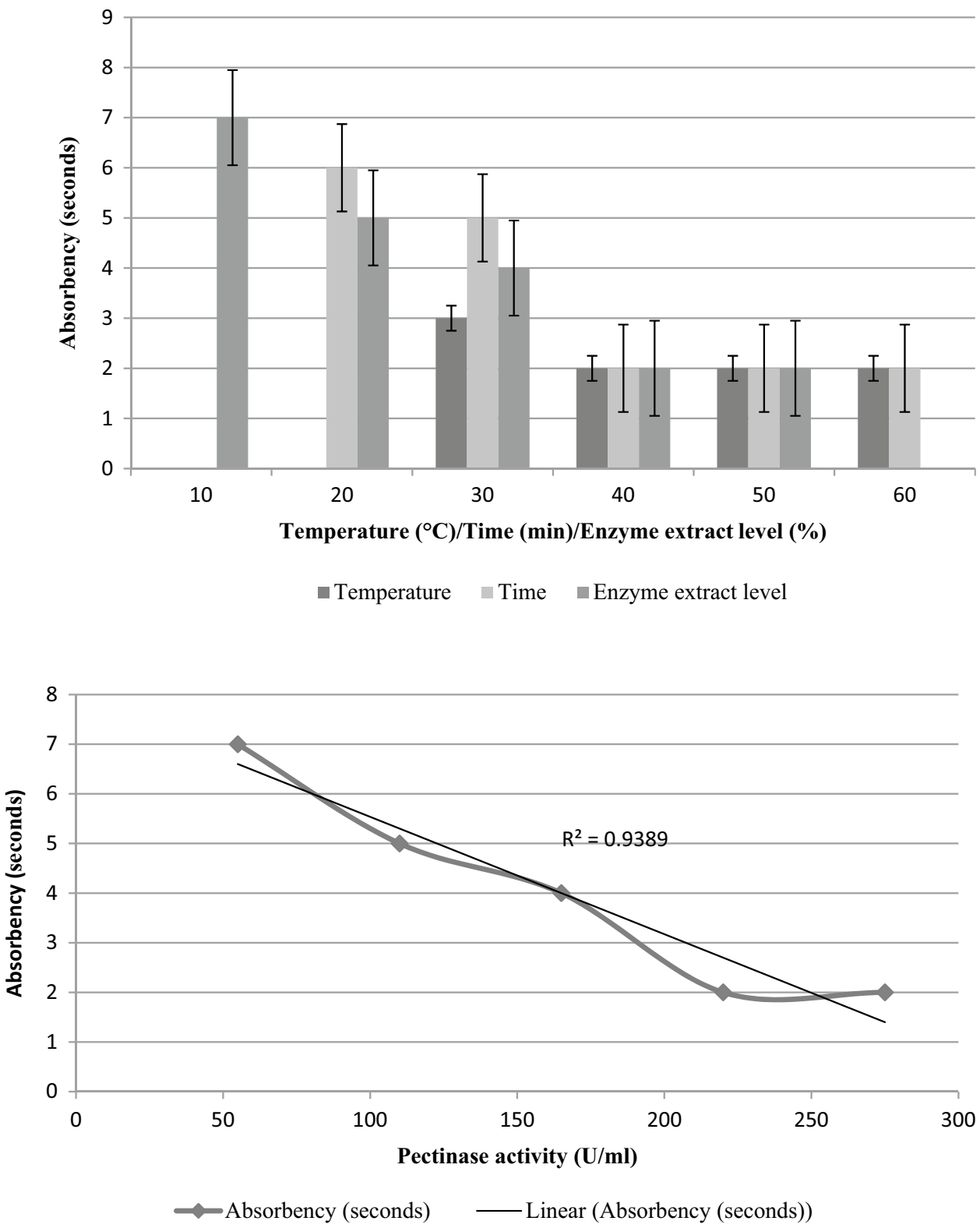

\section{Scale-Up of Enzyme Production}

Solid state fermentation is carried out in absence or near absence of water in which fungi is well adapted. The major factors considered for design of a solid state fermenter are type of the organism, substrate, inoculum level, $\mathrm{pH}$, temperature, particle size, aeration (agitation/mixing), moisture content etc. Tray fermentation has been widely used in solid state fermentation. Tray fermentation has been carried out under static conditions, unmixed beds with no mechanical agitation. The trays have been kept inside the fermenter to hold the substrate and to have a proper aeration [21]. In the present study, a solid state fermenter with three trays to hold the substrate was designed and developed to scale-up the enzyme production for bio-scouring treatment. The capacity of solid state fermenter is to produce $30 \mathrm{~L}$ of crude enzyme under batch condition. The different parts of the fermenter, inner view of the vessel and steel tray of the fermenter are depicted in Fig. 3. The average pectinase activity $(\mathrm{U} / \mathrm{ml})$ of crude enzyme of Aspergillus sp. VM-1 and P. flabellatus under three different fermentation batch conditions was 500 and 25 , respectively (results not shown).

\section{Characterization of Bio-scoured Cotton}

The properties of bio-scoured non-spinnable cotton under optimized conditions are given in Table 1. As per IP standard, the absorbent cotton should have the absorbency of $<10 \mathrm{~s}$, water holding capacity $>23 \mathrm{~g} / \mathrm{g}$ of fibre, sulphated ash $<0.5 \%$, wax $(<0.1)$ and pH 5-8 [2]. As indicated earlier 

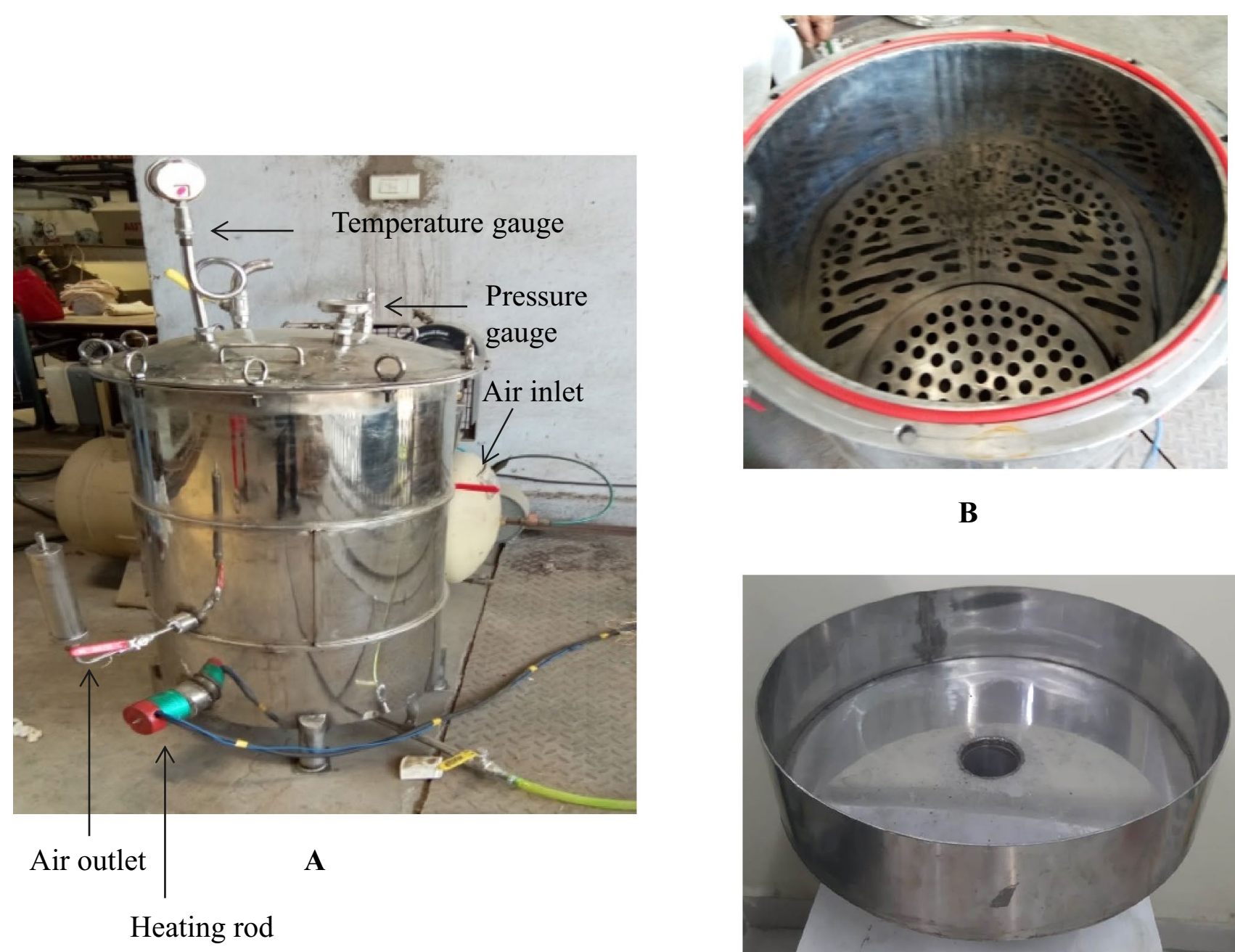

B

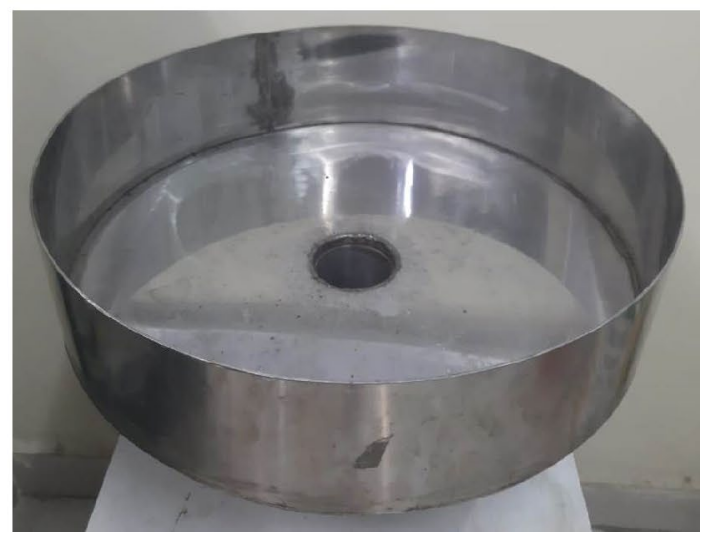

C

Fig. 3 Solid state fermenter (A components; $\mathbf{B}$ inner view; $\mathbf{C}$ tray)

Table 1 Properties of bioscoured non-spinnable cotton under optimized conditions

\begin{tabular}{lllll}
\hline Parameter & $\begin{array}{l}\text { Short staple } \\
\text { cotton }\end{array}$ & Cotton linters & $\begin{array}{l}\text { Non-woven cotton } \\
\text { fabric }\end{array}$ & $\begin{array}{l}\text { As per IP } \\
\text { standard }\end{array}$ \\
\hline Absorbency (s) & 2 & 2 & 2 & $<10$ \\
Water holding capacity (g/g) & 26 & 22 & 24 & $>23$ \\
Sulphated ash content (\%) & 0.22 & 0.4 & 0.24 & $<0.5$ \\
Residual wax content (\%) & 0.075 & 0.094 & 0.078 & $<0.1$ \\
$p \mathrm{H}$ & 6.5 & 6.0 & 6.2 & $5-8$ \\
\hline
\end{tabular}

in the optimization studies, the absorbency obtained in all the tested samples (SSC, CL and NWCF) was $2 \mathrm{~s}$. The water holding capacity (g/g) was higher in SSC (26) and lower in CL (22). The sulphated ash content (\%) was higher in CL (0.4) while lower in SSC (0.22). The residual wax content was lower in SSC (0.075) and higher in CL (0.094). The results indicate that the quality parameters of non-spinnable cotton evaluated under this study meet IP standards. However, the water holding capacity of CL is $22 \mathrm{~g} / \mathrm{g}$ as against the requirement $(>23 \mathrm{~g} / \mathrm{g}$ ) of standard. Thus, the results suggest that bio-scoured NWCF and SSC would be ideal for use in wipes and surgical applications. The bio-scoured nonspinnable cotton (SSC, CL and NWCF) is depicted in Fig. 4. As compared to chemical scouring, bio-scouring enhances 

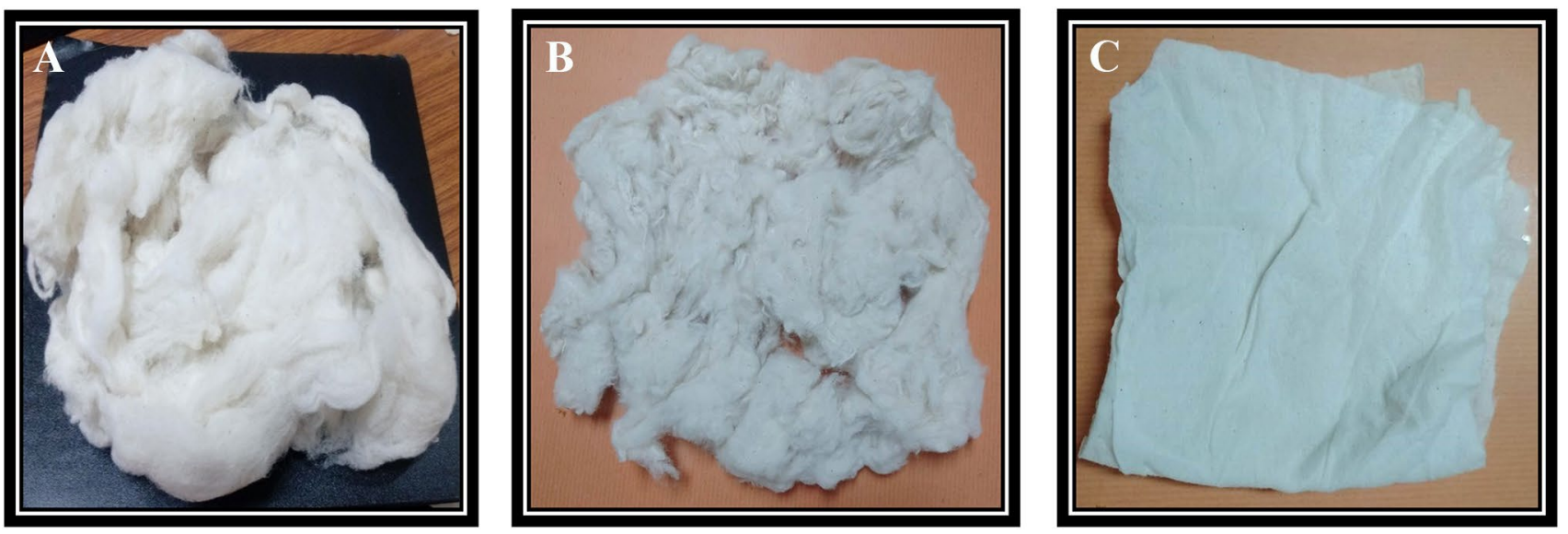

Fig. 4 Bio-scoured non-spinnable cotton (A short staple cotton; B cotton Linters; $\mathbf{C}$ non-woven cotton fabric)

the absorbency without appreciable loss in strength of the material. Because, bio-scouring target the primary cell wall where the non-cellulosic impurities are present while chemical scouring attacks randomly on primary and secondary cell wall $[22,23]$.

SEM analysis had been carried out to evaluate the surface modification of cotton fibre due to enzymatic treatment (Fig. 5). It is observed that the treated non-spinnable cotton (SSC, CL and NWCF) (Fig. (5B, 4D and 4F)) was more swollen than raw cotton (Fig. (5A, 4C and $4 \mathrm{E}$ )). The treated cotton was more of cylindrical than twisted while the untreated cotton was more of twisted than cylindrical. The treated cotton is loosened and some abrasions were observed. This might be due to action of pectinase in the crude enzyme which results in removal of wax content and pectic substances and improvement in absorbency of cotton [5].

\section{Economic Analysis}

The use of caustic soda under boiling temperature in conventional chemical scouring causes invisible weight loss of cotton fabric/fibre, huge water requirement for removal of residual chemical in fabric/ fibre and increase in chemical oxygen demand (COD) in the effluent. The chemical scouring causes health hazard to workers and environmental damage. In a similar study, the biological oxygen demand in bio-scoured and chemical scoured effluent was $2000 \mathrm{ppm}$ whereas the COD in bio-scoured and chemical scoured effluent was 5000 and 7500 ppm respectively [23]. Bioscouring minimizes the demand of energy, water, chemical and time and therefore costs.

The analysis of running cost to process one $\mathrm{kg}$ of nonspinnable cotton showed the raw material / substrate cost (USD 0.14), culture (Aspergillus sp. VM-1) cost (USD 0.042 ) and the process cost (USD 0.168). Thus, the total running cost to process one $\mathrm{kg}$ of non-spinnable cotton is USD 0.35 . The input quantity and the cost involved to process one kg of non-spinnable cotton are given in Table 2 . In a similar study, Jagajanantha et al. 2018 [24] reported Open Bath method using crude enzyme in which the capital investment and net profit for processing $100 \mathrm{~kg}$ of short staple cotton per day is USD 690 and 69, respectively. Conventional bio-scouring processes utilize 1.0 to $2.0 \%$ commercial pectinase based on weight of the material $[6,18$, 22 and 23] which costs between USD 0.28 and USD 0.55. Additional costs include logistics related to enzymes, energy for maintaining temperature between $55-60^{\circ} \mathrm{C}$, water, auxiliaries like sequestering agents etc. Accordingly, the process presented in this study is found to be more cost-effective than conventional bio-scouring. Based on findings of the this study, ten women farmers from Amravati District, Maharashtra, India were trained in bio-scouring of SSC for possible application in rural areas.

\section{Conclusions}

In the present study, the bio-scouring of non-spinnable cotton (SSC, CL and NWCF) using a crude enzyme produced by a new fungal strain, Aspergillus sp. VM-1 has been reported. Under optimized process conditions, the bioscoured non-spinnbale cotton had absorbency $(2 \mathrm{~s})$. The crude enzyme was mass produced using a newly designed solid state fermenter. The economic analysis showed that the cost involved in production of $1 \mathrm{~kg}$ of bio-scoured cotton is USD 0.35. Thus, the study offers a rural entrepreneurship potential especially in the region where cotton has been largely cultivated and processed. In continuation, a detail economic feasibility and commercial potential of this ecofriendly process may be taken up. 

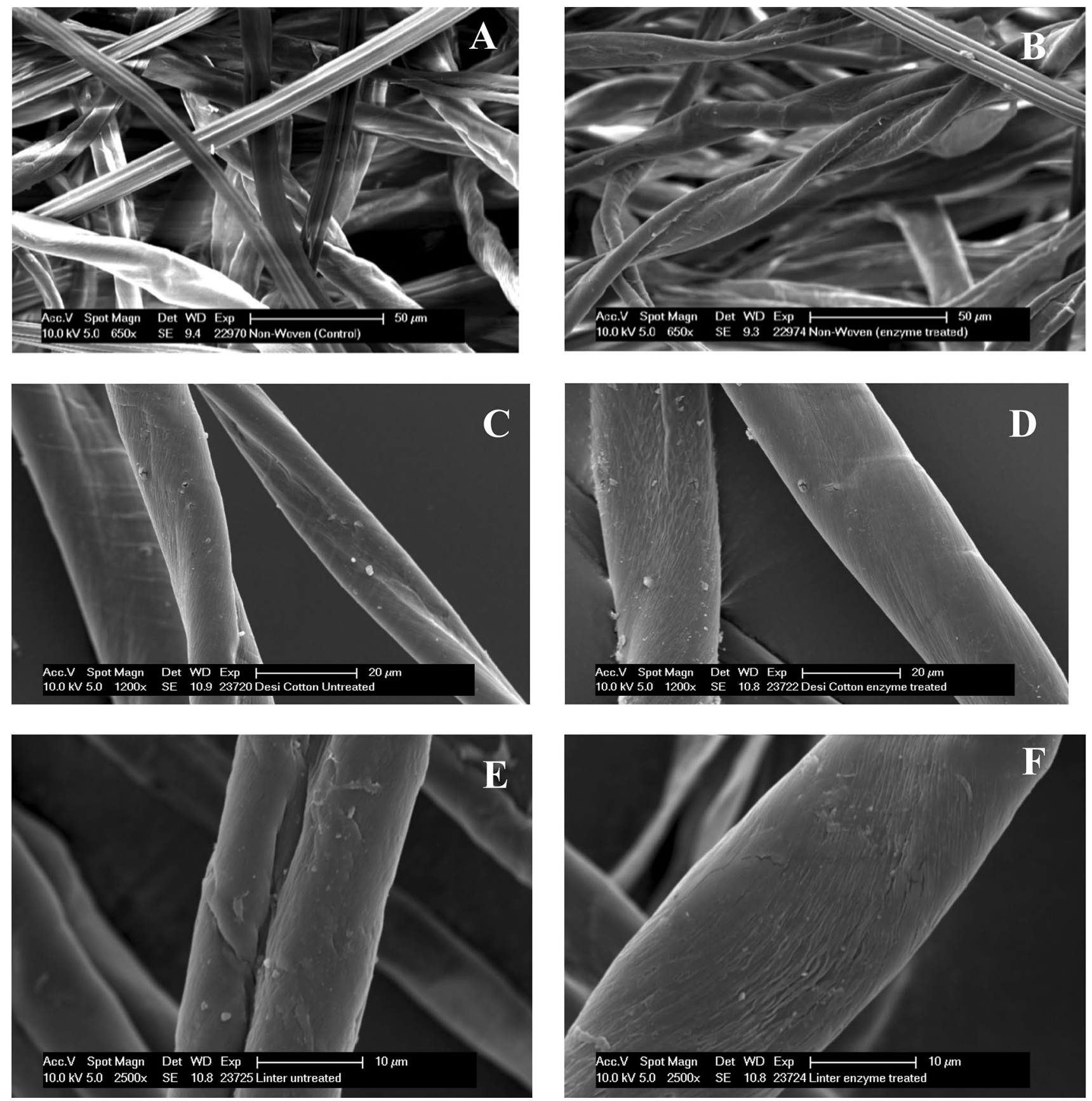

Fig. 5 SEM micrograph (A untreated non-woven cotton fabric; B treated non-woven cotton fabric; C untreated short staple cotton; D treated short staple cotton; $\mathbf{E}$ untreated cotton linters; $\mathbf{F}$ treated cotton linters)

Table 2 Running cost of bio-scouring to process one $\mathrm{kg}$ of non-spinnable cotton

\begin{tabular}{llrr}
\hline S. No & Item & Quantity & Cost (USD) \\
\hline 1 & Raw material/Substrate (Banana pseudo stem: cottonseed hulls and cottonseed meal; & $1 \mathrm{~kg}$ & \\
& $60: 30: 10)$ & $50 \mathrm{ml}$ & 0.14 \\
2 & Culture cost (Aspergillus sp. VM-1) & $1 \mathrm{~kg}$ & 0.042 \\
3 & Process cost (Sterilization, Fermentation, Extraction, Treatment and Labour cost) & 0.168 \\
Total & & 0.35 \\
\hline
\end{tabular}


Supplementary Information The online version contains supplementary material available at https://doi.org/10.1007/s12649-021-01621-9.

Funding This work was financially supported by ICAR Consortium Research Project on Natural Fibres (Grant No. CRP-CIRCOT-03).

Availability of Data and Material (Data Transparency) The ITS sequence of fungus for molecular identification was submitted in GenBank (http://www.ncbi.nlm.nih.gov) under accession number MT 568,613.1.

\section{Declarations}

Conflict of interest The authors declare no conflicts of interest, or competing financial or scientific interest.

Consent to Participate The authors declare consent to participate.

Consent for Publication The authors declare consent for publication.

\section{References}

1. CCI.: Mumbai (2020). https://cotcorp.org.in/shares.aspx. Accessed 15 March 2021.

2. Meena, R.A., Monga, D., Venugoplan, M.V., Ahuja, S.L., Sahay, R.: Screening of desi cotton (G. arboretum) suitable for surgical properties. J. Sci. Ind. Res. 75, 570-573 (2016)

3. Luitel, K.P., Hudson, D., Ethridge, D.: Evaluating cotton utilization in nonwoven textiles. J. Cotton Sci. 19, 298-306 (2015)

4. Hasan, M., Nabi, F., Mahmud, R.: Benefits of enzymatic process in textile wet processing. Int. J Fiber Text. Res. 5(2), 16-19 (2015)

5. Gayal, S.G., Nagarkar, R.D., Kambli, N.D., Kadam, R.P.: Ecofriendly absorbent cotton from non-spinnable fibres. J Cotton Res. Dev. 26(2), 261-271 (2012)

6. Raja, A.S.M., Arputharaj, A., Saxena, S., Patil, P.G.: A one bath chemo-enzymatic process for preparation of absorbent cotton. Perspect. Sci. 8, 254-256 (2016)

7. Pandey, A.: Solid State Fermentation. Wiley Eastern Limited, New Age International Publishers, New Delhi (1994)

8. Nigam, P.S., Pandey, A.: Biotechnology for Agro-industrial Residues Utilization. Springer, New Delhi (2009)

9. Imran, M., Asad, M.J., Hadri, S.H., Mehmood, S.: Production and industrial applications of laccase enzyme. J. Cell Mol. Biol. 10(1), $1-11(2012)$

10. Mageshwaran, V., Satankar, V., Jagajanantha, P.: Optimization of enzymatic process for preparation of absorbent cotton. Indian $\mathrm{J}$ Fibre Text Res. 44, 223-229 (2019)
11. White, T.J., Bruns, T.D., Lee, S.B., Taylor, J.W.: Amplification and direct sequencing of fungal ribosomal RNA genes for phylogenetics. In: PCR-Protocols and applications-a laboratory manual, Academic Press, New York, pp. 315-322 (1990)

12. Miller, G.L.: Use of dinitrosalicylic acid reagent for determination of reducing sugars. Anal. Chem. 31, 426-428 (1959)

13. Kavitha, K., Selvakumar, N.: Determination of sinking time of partially scoured cotton fibres. Int. J Fiber Text. Res. 36, 183-186 (2011)

14. Karapinar, E., Sariisik, M.O.: Scouring of cotton with cellulases, pectinases and proteases. Fibres Text. East Europe 12(3), 79-82 (2004)

15. Spicka, N., Zupin, Z., Kovac, J., Tavcer, P.E.F.: Enzymatic scouring and low-temperature bleaching of fabrics constructed from cotton, regenerated bamboo, poly(lactic acid), and soybean protein fibres. Fibres Polym. 16(8), 1723-1733 (2015)

16. Pereira, L., Bastos, C., Tzanov, T., Cavaco-Paulo, A., Guebitz, G.M.: Environmentally friendly bleaching of cotton using laccasses. Enivron. Chem. Lett. 3, 66-69 (2005)

17. Pandey, A.: Recent process development in solid state fermentation. Process Biochem. 27, 109-117 (1992)

18. Tzanov, T., Calafel, M., Guebitz, G.M., Cavaco-Poulo, A.: Biopreparation of cotton fabrics. Enzyme Microb. Technol. 29(6), 357-362 (2001)

19. Durairajan, B., Sankari, P.S.: Optimization of solid state fermentation conditions for the production of pectinases by Aspergillus niger. J Pharm Biosci. 2, 50-57 (2014)

20. Mojsov, K.: Enzyme scouring of cotton fabrics. A review. Int. J. Mark. Technol. 2(9), 256-275 (2012)

21. Manan, M.A., Webb, C.: Design aspects of solid state fermentation as applied to microbial processing. J. Appl. Biotechnol. Bioeng. 4(1), 511-532 (2017)

22. Bristi, V., Pias, A.K., Lavlu, F.H.: A sustainable process by bioscouring for cotton knitted fabric suitable for next generation. J. Text. Eng. Fashion Technol. 5(1), 41-48 (2019)

23. Rocky, A.M.K.B.P.: Comparison of effectiveness between conventional scouring and bio-scouring on cotton fabrics. Int. J. Sci. Eng. Res. 3(8), 1-5 (2012)

24. Jagajanantha, P., Mageshwaran, V., Satankar, V., Patil, P.G.: Ecofriendly process for absorbent cotton preparation for rural entrepreneurship. Int. J. Curr. Microbiol. Appl. Sci. 7(6), 1097-1103 (2018)

Publisher's Note Springer Nature remains neutral with regard to jurisdictional claims in published maps and institutional affiliations. 